\title{
Morphometry of human hyoid bone for sex determination
}

\author{
${ }^{1}$ Dr. Amrutha Roopa Ramagalla, ${ }^{2}$ Dr. Pulluri Sadanandam, ${ }^{3}$ Dr.T K Rajashree \\ ${ }^{1,3}$ Department of anatomy, Chalmeda Ananda Rao Institute of Medical sciences, Karimnagar, Telangana, India \\ ${ }^{2,}$ Department of Social Preventive Medicine, Kakatiya Medical College, Warangal, Telangana, India.
}

\begin{abstract}
The metric analysis of the hyoid bone is helpful technique in the sex determination of a skeleton. There is dearth in research work on the human hyoid bone regarding its weight and various other parameters for identifying the sex. In this study 56 male and 27 female bones in the age group of 15 - 75 years were collected from the human cadavers of known age and sex during autopsies. In most of the parameters there was a clear cut demarcation between the value of male and female bone. The range, mean, standard deviation and level of significance of all the fifteen parameters of the hyoid bone were calculated using the standard statistical method.
\end{abstract}

Keywords: hyoid bone, sex determination, anthropometry, greater cornu, lesser cornu.

\section{Introduction}

The U Shaped bone is suspended from the tips of the styloid process by the stylohyoid ligaments ${ }^{(9)}$.

Segments: The bone consists of a central part called the body and a pairs of cornua, the greater and the lesser cornua $^{(9)}$.

Body: The body is irregular, elongated and quadrilateral. Its anterior surface is convex, faces anterosuperiorly and is crossed by a transverse ridge with a slight downward convexity. A vertical median ridge often bisects the upper part of the body, but rarely extends to the lower part. The posterior surface is smooth, concave, faces posterioinferiorly, and is separated from the epiglottis by the thyrohyoid membrane and loose areolar tissue, there is a bursa between the hyoid bone and the membrane ${ }^{(9)}$.

Muscle attachments : Geniohyoid is attached to most of the anterior surface of the body, above and below the transverse ridges the medial part of hyoglossus invades the lateral geniohyoid area ${ }^{(9)}$.

The lower anterior surface gives attachment to mylohyoid the line of attachment lying above sternohyoid medially and omohyoid laterally. The lowest fibres of genioglossus, the hyoepiglottic ligament and the thyrohyoid membrane are all attached to the rounded superior border. Sternohyoid is attached to the inferior border medially and omohyoid is attached laterally. Occasionally, the medial fibres of thyrohyoid and, when present, of levator glandulae thyroideae, are attached along the inferior border ${ }^{(9)}$.

Greater cornua: In early life, the greater cornua are connected to the body by cartilage, but after middle age they are usually united by bone. They project backwards (curving posterolaterally) from the lateral ends of the body. They are horizontally flattened, taper posteriorly, and each ends in a tubercle, when the throat is gripped between finger and thumbs above the thyroid cartilage, the greater cornua can be identified and the bone can be moved from side to side ${ }^{(9)}$.

Muscle attachments : The middle pharyngeal constrictor and, more laterally, hyoglossus, are attached along the whole length of the upper surface of each greater cornu. Stylohyoid is attached near the junction of the cornu with the body. The fibrous loop for the digastric tendon is attached laterally and a little posterior to hyoglossus. The thyrohyoid membrane is attached to the medial border and thyrohyoid muscle is attached to the lateral border. The oblique inferior surface is separated from the thyrohyoid membrane by fibroareolar tissue ${ }^{(9)}$. Lingual artery arises from the front of the external carotid opposite to the tip of greater cornu, facial artery arises from the front of the external carotid just above the tip of the greater cornu ${ }^{(9)}$.

Lesser cornua: The lesser cornua are two small conical projections at the junctions of the body and greater cornua. At its base, each is connected to the body by fibrous tissue and occasionally to the greater cornu by a synovial joint which occasionally becomes ankylosed ${ }^{(9)}$.

Muscle attachment : The middle pharyngeal constrictors are attached to the posterior and lateral aspects of the lesser cornua. The stylohyoid ligaments are attached to their apices and are often partly calcified, and the chondroglossi are attached to the medial aspects of their bases ${ }^{(9)}$.

Development of the hyoid bone: The hyoid bone develops from cartilages of the second and third pharyngeal arches, the lesser cornua from the second, the greater cornua from the third and body from the fused ventral ends of both. Chondrification begins in the fifth fetal week in these elements and is completed in the third and fourth months ${ }^{(9)}$.

Ossification: Ossification proceeds from six centeres i.e., a pair for the body and one for each cornu. Ossification begins in the greater cornua towards the end of intrauterine life, in the body shortly before or after 
birth, and in the lesser cornua around puberty. The greater cornual apices remain cartilaginous until the third decade and epiphyses may occur here. They fuse with the body. Synovial joints between the greater and lesser cornua may be obliterated by ossification in later decades ${ }^{(9)}$.

The metric analysis of the hyoid bone is helpful technique in the sex determination of a skeleton ${ }^{(1)}$. The present authors developed interest in studying the hyoid bone by using the various parameters.

\section{Meterial and methods}

The material for the present study include 83 specimens of hyoid bones collected from the cadavers during autopsies at Osmania General Hospital, Hyderabad from 2010 - 2013. The specimens were selected out of 350 medico legal cases in the age group of $15-75$ years. Some of the hyoid bones obtained were damaged particularly those of hanging and strangulation cases. So, they were excluded from the present study.

Before starting the autopsy, age and sex of the cadaver was recorded. Then autopsy was done to mobilize and remove the hyoid bone from the body. The traditional method described in the text book of autopsy diagnosis and technique by Otto Saphir ${ }^{(5)}$ was adapted.

The following measurements were taken with the help of Vernier Caliper (1 to 14 parameters are in $\mathrm{mm})$ and electronic weighing machine ( $15^{\text {th }}$ parameter in grams).

1. Length of the greater cornu - right.

2. Length of the greater cornu - left.

3. Transverse distance between tubercles of greater cornua - External (outer measurement).

4. Transverse distance between tubercles of greater cornua- Middle(central measurement).

5. Transverse distance between tubercles of greater cornua-

Internal(inner measurement).

6. Distance between internal surfaces of the greater cornua at their middle.

7. Length of the lesser cornu - right.

8. Length of the lesser cornu - left.

9. Minimum transverse distance between bases of lesser cornua.

10. Side to Side dimension (width) of the body in the middle.

11. Antero-posterior dimension of body in the middle.

12. Distance between the upper and lower margins of the body (height).

13. Vertical distance between middle of the anterior surface of the body and transverse line drawn between the tubercles of greater cornua in the midline.

14. Maximum depth of concavity on the posterior surface of the body in the middle.

15. Weight after defatting.

Data was designed on a master chart and analysed statistically using the standard statistical method (one sample t-test).

III. Results

Table: 1 Number of samples used in this study

\begin{tabular}{|l|l|l|l|}
\hline Age in years & Males & Females & Total \\
\hline $0-10$ & 0 & 0 & 0 \\
\hline $11-20$ & 0 & 5 & 5 \\
\hline $21-30$ & 4 & 6 & 10 \\
\hline $31-40$ & 13 & 2 & 15 \\
\hline $41-50$ & 18 & 11 & 29 \\
\hline $51-60$ & 13 & 3 & 16 \\
\hline $61-70$ & 8 & 0 & 8 \\
\hline $71-80$ & 0 & 0 & 0 \\
\hline
\end{tabular}

Table: 2 Statistical Analysis of all 15 parameters of Hyoid Bone in Adult Male and Female (15 - 75 years) 1- 15 parameters in $\mathbf{m m}$ and $15^{\text {th }}$ parameter in grams

\begin{tabular}{|c|c|c|c|c|c|c|}
\hline \multirow{2}{*}{$\begin{array}{l}\mathbf{S} . \\
\mathbf{N} \\
\mathbf{0}\end{array}$} & \multirow[b]{2}{*}{ Parameters } & \multicolumn{2}{|l|}{ Males $(\mathrm{N}=56)$} & \multicolumn{2}{|c|}{ Females $(\mathrm{N}=27)$} & \multirow{2}{*}{$\begin{array}{l}\text { Level of } \\
\text { Significance }\end{array}$} \\
\hline & & Mean \pm S.D & Range & Mean \pm S.D. & Range & \\
\hline 1 & $\begin{array}{l}\text { Length of greater cornu } \\
\text { right }\end{array}$ & $\begin{array}{l}32.08 \\
2.053\end{array}$ & $28-37$ & $28.74 \pm 2.455$ & $24-32.5$ & $\mathrm{P}<0.0001$ \\
\hline 2 & $\begin{array}{l}\text { Length of greater cornu } \\
\text { left }\end{array}$ & $\begin{array}{l}32.02 \\
2.009\end{array}$ & $28-37$ & $28.69 \pm 2.399$ & $24-33$ & $\mathrm{P}<0.0001$ \\
\hline 3 & \begin{tabular}{ll} 
Transverse & \multicolumn{2}{c}{ distance } \\
between tubercle of
\end{tabular} & $\begin{array}{l}44.60 \\
7.945\end{array}$ & $31-70$ & $38.50 \pm 4.975$ & $31-48$ & $\mathrm{P}<0.0001$ \\
\hline
\end{tabular}




\begin{tabular}{|c|c|c|c|c|c|c|c|}
\hline & greater cornua (external) & & & & & & \\
\hline 4 & Middle & $\begin{array}{l}41.04 \\
7.672\end{array}$ & & $28-66$ & $35.35 \pm 5.964$ & $25-45$ & $\mathrm{P}<0.0001$ \\
\hline 5 & Internal & $\begin{array}{l}37.26 \\
7.750\end{array}$ & \pm & $23-62$ & $32.70 \pm 5.686$ & $22-42$ & $\mathrm{P}<0.0001$ \\
\hline 6 & $\begin{array}{l}\text { Distance between internal } \\
\text { surface of greater cornua } \\
\text { at their middle }\end{array}$ & $\begin{array}{l}33.13 \\
4.974\end{array}$ & & $22-43$ & $28.26 \pm 2.736$ & $24-33$ & $\mathrm{P}<0.0001$ \\
\hline 7 & $\begin{array}{l}\text { Length of lesser cornu } \\
\text { right }\end{array}$ & $5.6 \pm 1.23$ & & $3.50-10.0$ & $4.7 \pm 0.700$ & $3.50-6.0$ & $\mathrm{P}<0.0001$ \\
\hline 8 & Length of lesser cornu left & $5.6 \pm 1.23$ & & $3.50-10.0$ & $4.7 \pm 0.700$ & $3.50-6.0$ & $\mathrm{P}<0.0001$ \\
\hline 9 & $\begin{array}{l}\text { Minimum transverse } \\
\text { distance between bases of } \\
\text { lesser cornua }\end{array}$ & $21.47 \pm 3$ & & $11.5-28$ & $18.6 \pm 2.89$ & $10.5-22$ & $\mathrm{P}<0.0001$ \\
\hline 10 & $\begin{array}{l}\text { Width of body in the } \\
\text { middle }\end{array}$ & $\begin{array}{ll}22.642 \\
3.171\end{array}$ & & $13.5-28$ & $\begin{array}{ll}20.370 \quad \pm \\
1.596 & \\
\end{array}$ & $18-23$ & $\mathrm{P}<0.0001$ \\
\hline 11 & $\begin{array}{l}\text { Antero-posterior } \\
\text { dimension of body in the } \\
\text { middle }\end{array}$ & $\begin{array}{l}6.223 \\
1.253\end{array}$ & & $4-9$ & $5.537 \pm 1.208$ & $4-8$ & $\mathrm{P}<0.0001$ \\
\hline 12 & $\begin{array}{l}\text { Distance between the } \\
\text { upper and lower margins } \\
\text { of body in the middle } \\
\text { height }\end{array}$ & $\begin{array}{l}11.857 \\
1.554\end{array}$ & & $9-17$ & $10.00 \pm 1.074$ & $7-11.5$ & $\mathrm{P}<0.0001$ \\
\hline 13 & $\begin{array}{l}\text { Vertical distance between } \\
\text { middle of the arterior } \\
\text { surface of the body and } \\
\text { transverse line drawn } \\
\text { between tubercles of } \\
\text { greater cornua in the } \\
\text { midline }\end{array}$ & $\begin{array}{l}36.812 \\
3.160\end{array}$ & & $30-44$ & $\begin{array}{l}32.314 \\
2.446\end{array}$ & $26-36$ & $\mathrm{P}<0.0001$ \\
\hline 14 & $\begin{array}{l}\text { Maximum depth of } \\
\text { concavity on the post } \\
\text { surface of the body in the } \\
\text { middle }\end{array}$ & $\begin{array}{l}1.8393 \\
0.647\end{array}$ & & $1-3$ & $1.537 \pm 0.535$ & $1-2.5$ & $\mathrm{P}<0.0001$ \\
\hline 15 & Weight after defatting (g) & $\begin{array}{l}0.9974 \\
0.255\end{array}$ & & $0.67-1.79$ & $\begin{array}{ll}0.7216 & \pm \\
0.1154 & \end{array}$ & $0.49-0.90$ & $\mathrm{P}<0.0001$ \\
\hline
\end{tabular}

\section{Discussion}

It is observed that the male hyoid bone values are more $(11.85 \pm 1.55 \mathrm{~mm})$ when compared to female $(10.00 \pm 1.07 \mathrm{~mm})$ regarding the distance between the upper and lower margins of body in the middle (height). The $p$ value is statistically significant in both sexes. The present study is correlating with other studies ${ }^{(2,4 \& 7)}$. The male hyoids are larger than female hyoids in all parameters, the present study is similar with Harjeet and Jit $\mathrm{I}^{(2)}$, the difference being statistically significant ( $\mathrm{p}$ value $<0.001$ ).

Table: 3 Comparision of Harjeet and Jit $\mathrm{I}^{(2)}$ study with the present study

\begin{tabular}{|l|l|l|l|l|}
\hline Parameter & Harjeet and Jit I(2) & \multicolumn{1}{l|}{ Present study } \\
\hline 1 & $33.59 \pm 2.76$ & $29.79 \pm 2.75$ & $32.08 \pm 2.053$ & $28.74 \pm 2.455$ \\
\hline 2 & $33.90 \pm 2.84$ & $29.66 \pm 2.38$ & $32.02 \pm 2.009$ & $28.69 \pm 2.399$ \\
\hline 3 & $44.59 \pm 6.31$ & $38.65 \pm 4.85$ & $44.60 \pm 7.945$ & $38.50 \pm 4.975$ \\
\hline 4 & $44.65 \pm 6.32$ & $35.56 \pm 5.03$ & $41.04 \pm 7.672$ & $35.35 \pm 5.964$ \\
\hline 5 & $37.24 \pm 5.84$ & $31.82 \pm 4.76$ & $37.26 \pm 7.750$ & $32.70 \pm 5.686$ \\
\hline 6 & $33.42 \pm 3.38$ & $27.65 \pm 3.08$ & $33.13 \pm 4.974$ & $28.26 \pm 2.736$ \\
\hline 7 & $7.25 \pm 2.05$ & $6.32 \pm 1.53$ & $5.6 \pm 1.23$ & $4.7 \pm 0.700$ \\
\hline 8 & $7.05 \pm 1.70$ & $6.42 \pm 1.50$ & $5.6 \pm 1.23$ & $4.7 \pm 0.700$ \\
\hline 9 & $24.45 \pm 2.35$ & $20.48 \pm 2.42$ & $21.47 \pm 3$ & $18.6 \pm 2.89$ \\
\hline 10 & $24.03 \pm 2.36$ & $20.29 \pm 1.55$ & $22.642 \pm 3.171$ & $20.370 \pm 1.596$ \\
\hline 11 & $6.58 \pm 1.88$ & $5.10 \pm 0.95$ & $6.223 \pm 1.253$ & $5.537 \pm 1.208$ \\
\hline 12 & $11.04 \pm 1.10$ & $9.47 \pm 1.08$ & $11.857 \pm 1.554$ & $10.00 \pm 1.074$ \\
\hline 13 & $38.66 \pm 3.29$ & $34.05 \pm 2.82$ & $36.812 \pm 3.160$ & $32.314 \pm 2.446$ \\
\hline 14 & $2.40 \pm 0.70$ & $2.23 \pm 0.67$ & $1.8393 \pm 0.647$ & $1.537 \pm 0.535$ \\
\hline 15 & $1.20 \pm 0.31$ & $0.80 \pm 0.23$ & $0.9974 \pm 0.255$ & $0.7216 \pm 0.1154$ \\
\hline
\end{tabular}

The previous authors studied on the transverse distance between tubercles of greater cornua External $^{(2) \&(7)}$ and the transverse distance between tubercles of greater cornua- Middle ${ }^{(2)(3)(4) \&(8)}$ results were greater in male hyoids than in female hyoids. The present study result is the mean length of the greater cornu- 
external (right) in males is $32.08 \pm 2.05 \mathrm{~mm}$ and in females it is $28.74 \pm 2.45 \mathrm{~mm}$, the mean length of the greater cornu (left) in males is $32.02 \pm 2.009 \mathrm{~mm}$ and in females is $28.69 \pm 2.39 \mathrm{~mm}$, the result of this parameter female values are less than the male value. The obtained value is highly significant ( $\mathrm{p}$ value $<0.001$ ).

The mean vertical distance between middle of the anterior surface of the body and transverse line drawn between the tubercles of greater cornua in the midline in males is $36.812 \pm 3.16 \mathrm{~mm}$ and in females it is $32.31 \pm 2.44 \mathrm{~mm}$, the difference being statistically significant ( $\mathrm{p}$ value $<0.001$ ). The present study is correlating with Harjeet and $\mathrm{Jit} \mathrm{I}^{(2)}$ and Igor Leksan et $\mathrm{al}^{(3)}$. The mean vertical distance between middle of the anterior surface of the body and transverse line drawn between the tubercles of greater cornua in the midline is greater in males than in females.

According to Ranjith and Pillai $\mathrm{S}^{(6)}$ the mean weight of the hyoid bone in male was $1474.40 \pm$ $289.66 \mathrm{mg}$ and that of the female hyoid bone was $960 \pm 233.37 \mathrm{mg}$. In the present study, the mean weight after defatting in male hyoids is $0.9974 \pm 0.255$ grams and in female hyoids it is $0.7216 \pm 0.1154$ grams, the present value is statistically significant ( $\mathrm{p}$ value $<0.001$ ). The present study is in accordance with previous reports ${ }^{(2)} \&(6)$. The mean weight after defatting is greater in males than in females.

\section{Conclusion}

The readings of the male bone for the most of the parameters were more when compared to the values of female bones. In most of the parameters there was a clear cut demarcation between the value of male and female bone. For determining sex in these bones, single parameter may not be sufficient to decide the sex of the bones and it becomes mandatory to view all the parameters before deciding the sex of an unknown hyoid bone.

\section{Acknowledgement}

The authors are grateful to professor Dr. T K Rajashree Dept. of anatomy. and also wish to thank Department of forensic medicine, Osmania Medical College, Hyderabad.

\section{References}

[1]. E.M.Reesink, A. A. H. Van Immerseel, R. Brand, Tj. D. Bruintjes; 1999: International Journal osteoorchaeol, 9(5): 357-360.

[2]. Harjeet and Jit I; 1996: Shape, Size and Sexual dimorphism of the hyoid bone in northwest Indians. Journal of Anatomical Society of India. Vol.45 (1): 4-22.

[3]. Igor Leksan, Mladen Marcikic, Vasilije Nikolic, Radivoje Radic and Robert Selthofer; 2005: Morphological classification and sexual dimorphism of hyoid bone - (scientific paper) coll. Antropol 29 (1): $237-242$.

[4]. Miller KWP, Walker PL, O’ Halloran RL; 1998: Age and Sex related variation in hyoid bone morphology: Journal Forensic 43 (6): 1138-1143.

[5]. Otto Saphire (1958): $4^{\text {th }}$ edition. The text book of Autopsy Diagnosis and Technique.

[6]. Ranjith and Pillai S; 1988: A Post mortem study of 100 hyoid bones using weight as parameter. Journal of Indian Academy of Forensic Medicine. 10: 31-33.

[7]. Sarah C Kindschuh; 2007: Thesis At The University Of Central Florida, Orlando, Florida. Determining sex and Ancestry of the hyoid from the Robert J. Terry Anatomical collection.

[8]. Seham A. Gad El. Hak; Sahar A. El. Dakroory; Adel A. El. Hawary and Amr M. Alghazally; 2007: Sexual Dimorphism of the hyoid bone. A primary study - Journal of Forensic Med. Clin. Toxicol. Vol. XV, No.1.

[9]. Susan Standring et al; 2008: Text book of Grays Anatomy $-40^{\text {th }}$ edition - Gross Anatomy- Celsevier, Churchill. Livingstone. 